\title{
PSIKOLOGIS DALAM SENI: KATARSIS SEBAGAI REPRESENTASI DALAM KARYA SENI RUPA
}

\author{
Ernawati \\ Fakultas Teknik, Universitas Maarif Hasyim Latif \\ Email : ernawati@dosen.umaha.ac.id \\ Diterima : 10 Agustus 2019. Disetujui : 5 November 2019. Dipublikasikan : 27 Desember 2019 \\ (C)2019 - DESKOVI Universitas Maarif Hasyim Latif. Ini adalah artikel dengan akses \\ terbuka di bawah lisensi CC BY 4.0 (https://creativecommons.org/licenses/by/4.0/)
}

\begin{abstract}
ABSTRAK
Tujuan penelitian ini adalah mengungkap peran aspek psikologis katarsis dalam karya seni rupa. Prinsip seputar psikis dapat dipraktikan dalam karya seni, salahsatunya gerakan seni rupa kontemporer. Kajian karya berdasarkan aspek psikologis, salah satunya katarsis termasuk hal yang krusial untuk dilakukan. Metode pada penelitian ini menerapkan metode kualitatif dengan pendekatan multidisiplin (psikologi seni dan semiotika). Hasil penelitian menunjukkan bahwa Perspektif lebih obyektif karena seniman sebagai kreator berbanding lurus dengan karya yang disajikan. Elemen visual yang dipilih dan disajikan seniman tersusun berdasarkan kemampuan kreatif menyusun citra visual yang berangkat dari aspek pengalaman yaitu berupa rasa khawatir/kegelisahan atau ketakutan yang mendasarinya dalam berkarya. Karya seni yang terwujud representasi dari dunia psikis seniman sebagai kreator. Pendekatan psikologis dalam berkarya dengan dipadukan kemampuan akademik dari aspek keilmuan seni rupa setidaknya mampu memperkaya keilmuan dalam keberagaman seni rupa. Dalam konstelasi seni rupa Indonesia kontemporer, kajian dari perspektif psikologis, khususnya katarsis pada karya seni berelasi dengan psikobiografi atau pengalaman pribadi seniman.
\end{abstract}

Kata kunci: Katarsis, Karya Seni Rupa

\section{ABSTRACT}

This research aims to explore the role of catharsis psychological aspects in visual artwork. The principle surrounding the psychic can be practiced in the artwork. One of them is contemporary art movements. A study of works based on psychological aspects, one of which is cathartic includes the crucial thing to do. The method in this study implements a qualitative method with a multidisciplinary approach (the psychology of Art and semiotics). The results show that perspective is more objective because the artist as a creator is directly proportional to the work showed.The selected and presented visual elements by the artist are arranged based on a creative ability to compose a visual image that influences the experience aspect of worry/anxiety or fear underlying it in the works. The artwork embodied is a representation of the part of a psychic artist as creator. The psychological approach of working combined with the academic ability of the science aspect of the arts is at least, capable of enriching science in the diversity of visual arts. In the constellation of contemporary Indonesian visual art, a study from a psychological perspective, especially catharsis on artwork relates to a psychobiography or an artist's personal experience.

Keyword: catharsis, visual artwork

\section{PENDAHULUAN}

Manusia terlahir ke muka bumi dengan tubuh yang terdiri atas berbagai lapisan kesadaran. Lapisan tubuh tersebut meliputi dua aspek yang saling berhubungan yaitu tubuh fisik dan lapisan energi. Sifat tubuh fisik dapat terindera oleh panca indera, tersentuh oleh panca indera manusia, sementara lapisan energi yang terdiri atas lapisan emosional, lapisan intelegensia dan lapisan kesadaran murni tidak mampu terjangkau oleh indera secara kasar. Keabstrakan dan kehalusan lapisan energi ini, melibatkan atau sebagai bagian dari aspek psikologis. Aspek psikologis ikut berperan dalam kretifitas berkesenian, salahsatunya adanya trauma dan katarsis sebagai bagian dari alur cerita atau representasi karya maupun sebagai pengalaman yang membawa jalan berkarya seni sebagai media katarsis ataupun pelepasan kegelisahan.

Kehidupan manusia yang bergerak dinamis, mengajak pada keadaan kehidupan yang cukup kompleks dan beragam. Pada kenyataan hidup dititik tertentu, akan membawa pada tahap kesadaran akan keterbatasan akan kemampuan yang dimilki diri pribadi manusia. Keterbatasan tersebut ketika tidak mampu disikapi dengan bijak akan membawa manusia pada rasa emosional yang memuncak dan cenderung pada 
frustasi yang terus bergejolak. Rasa emosi, gelisah dan frustasi pada titik puncak perlu disalurkan supaya tidak meledak dan menghancurkan insan manusia, sehingga mampu menguasai dirinya. Penyaluran emosi tersebut tidak harus disalurkan secara nyata dengan kata-kata namun dapat dilakukan dengan proses katarsis melalui berkarya seni. Pelepasan emosi yang terpendam berperan penting bagi orang yang dalam masalah emosional. Dalam ilmu psikologi katarsis dikenal dalam proses konseling Freud.( Singgih D.Gunars, 1992:106)

Selain elemen visual yang terdapat dalam karya seni rupa, faktor individu seniman selaku kreator di baliknya dapat pula ditinjau secara psikologis. Dalam konteks psikologi modern dikenal psikoanalisis yang mengungkapkan pergulatan mental dalam ketidaksadaran yang tersembunyi. Konflik internal cita-cita, mimpi, khayalan, ketakutan, yang dialami seniman inilah (sisi ekstrinsik) yang sejatinya diungkapkan dalam karyanya, khususnya melalui elemen-elemen visualnya (intrinsik). Dengan kata lain, aspek visual tersebut dapat dikaji dari sisi psikologis juga. Salahsatu sisi psikologis yang kerap menjadi konsep berkarya seniman yaitu ketakutan atau kegelisahan dari kehidupan yang mereka lalui. Hal ini dikenal dengan khatarsis, yaitu pelepasan emosi akan jiwa seniman.

Setiap manusia memiliki cara yang unik dan bervariasi dalam melakukan katarsis sebagai proses pelepasan emosi, begitupun dengan seniman melalui katarsis seakan menceritakan masalah yang dialaminya melalui citra visual yang dihadirkan dalam karya. Berkarya dengan berangkat dari kegelisahan tidak dapat dipungkiri, sering menjadi cerita sebagai babak awal terciptanya karya yang bersifat mengakar dan kuat.Melihat kondisi tersebut peneliti merasa tertarik untuk mengadakan pembahasan topik katarsis dalam karya seni, khususnya seni rupa guna mengetahui seberapa besar manfaat terapi katarsis dalam mengatasi trauma. Mengadakan upaya pembacaan ulang terhadap seniman dan karyanya berdasarkan analisa katarsis, sebagai salah satu upaya menjangkau kesadaran seniman. Menyelami konflik intim yang termuat dalam karya baik secara wujud fisik visual karya maupun berdasarkan pemaknaan yang menumbuhkan pemunculan akan fungsi logika imajinasi karya. Oleh karena itu, penulis merasa hal ini penting untuk dikaji, untuk mengetahui sejauh mana pemanfaatan terapi katarsis yang dilakukan oleh seniman dalam alur berkesenian. Berdasarkan hal tersebut penulis tertarik untuk mengadakan penelaahan dan pemahaman dengan memilih topik “ Katarsis sebagai Representasi dalam Karya Seni Rupa” .

\section{METODE PENELITIAN}

\section{Pengumpulan Data}

a. Alasan pemilihan kasus
Pada proses penelitian ini, peneliti mengambil topik tentang katarsis sebagai representasi dalam karya seni rupa. Peneliti memilih topik tersebut, karena pentingnya katarsis dari traumatis sebagai alternatif media pelepasan emosi yang dilakukan oleh seniman melalui karya seni. Oleh sebab itu, perlu membaca karya seni yang berdasarkan katarsis dari traumatis/kegelisahan, sebagai alternatif kasus yang menggambarkan sejauh mana peran katarsis melalui karya seni rupa .

\section{b. Jenis Penelitian}

Dalam penelitian ini, menggunakan metode penelitian kualitatif dengan pendekatan multidisiplin (psikoanalisis dan semiotika). Fokus kajian penelitian ini adalah katarsis dari traumatis yang direpresentasikan dalam karya seni rupa.

\section{Psikoanalisis}

Psikoanalisis merupakan salah satu aliran besar dalam sejarah ilmu pengetahuan manusia. Layaknya aliran besar lainnya, Marxisme contohnya, psikoanalisis telah merambah berbagai sektor keilmuan seperti sastra, sosiologi, filsafat, dan kesenian. Psikoanalisis awalnya identik dengan nama pendirinya, Sigmund Freud, sehingga penggunaan istilah psikoanalisis dan psikoanalisis Freud awalnya memiliki arti yang sama. Namun, kemudian beberapa murid Freud yang beralih dari ajaran gurunya memilih untuk meninggalkan istilah psikoanalisis; seperti Carl Gustav Jung yang memilih menggunakan nama psikologi analitis (analytical psychology) dan Alfred Adler dengan istilah psikologi individual (individual psychology). Seiring meluasnya penerimaan psikoanalisis dalam ruang keilmuan yang beragam, istilah tersebut akhirnya tidak hanya identik dengan Freud. Psikoanalisis kali pertama dikembangkan di Wina pada tahun 1890-an oleh Sigmund Freud (1947), seorang akhli syaraf berkebangsaan Austria yang memiliki ketertarikan untuk menemukan suatu penanganan yang efektif bagi para pasien dengan gejala neurosis atau histeris. Dari hasil perbincangannya dengan para pasien tersebut Freud menjadi yakin bahwa tindakan dan perilaku individu saat ini dipicu oleh trauma kejiwaan pada masa sebelumnya. Freud menyimpulkan bahwa pikiran manusia jauh lebih rumit daripada anggapan yang berkembang selama ini, dan kerumitan inilah yang mendorong banyak manusia untuk membentuk pemikiran-pemikiran yang tidak dapat diterima secara sosial atau membuat keputusan yang berbahaya. Bentuk asli psikoanalisis Freud sangat terfokus pada fantasi seksual yang ditekan oleh pasien dan pengalaman pada awal masa kanakkanak. Freud berharap dapat membantu pasiennya berhadapan dengan kenangan-kenangan traumatis dalam lingkungan yang aman untuk memahami kesulitankesulitannya (Adams, 1996:180). Berikut ini adalah ilustrasi tentang pandangan Freud mengenai pikiran manusia (human mind) yang dianalogikannya bagaikan 
sebongkah gunung es yang terapung-apung di tengah lautan, di antara kesadaran (consciousness) dan ketaksadaran (unconsciousness):

\section{Semiotika}

Secara etimologis istilah semiotik atau ada yang menyebut dengan semiotika berasal dari bahasa Yunani "semeion" yang berarti 'tanda'. Istilah semeion tampaknya diturunkan dari kedokteran hipokratik atau asklepiadik dengan perhatiannya pada simtomatologi dan diagnostik inferensial (Alex, 2006: 95). Tanda itu sendiri didefinisikan sebagai sesuatu yang atas dasar konvensi sosial yang terbangun sebelumnya, dapat dianggap mewakili sesuatu yang lain. Secara terminologis, semiotika dapat didefinisikan sebagai ilmu yang mempelajari sederetan luas objekobjek, peristiwa-peristiwa, seluruh kebudayaan sebagai tanda. Semiotika bisa juga didefinisikan sebagai ilmu yang mengkaji tanda dalam kehidupan manusia. Karena manusia memiliki kemampuan untuk memberikan makna kepada berbagai gejala sosial budaya dan alamiah, maka semiotik dapat disimpulkan bahwa tanda adalah bagian dari kebudayaan manusia.

Semiotika merupakan studi tentang tanda dan segala sesuatu yang berhubungan dengannya: cara berfungsinya, hubungannya dengan tanda-tanda lain, pengirimannya, dan penerimaannya oleh mereka yang mempergunakannya (Alex Sobur, 2004: 15). Semiotik adalah suatu ilmu atau metode analisis untuk mengkaji tanda. Semiotika adalah ilmu yang secara sistematis mempelajari tanda-tanda, lambang-lambang, sistem-sistemnya dan prosesnya (Panuti,1992:5).

Semiotika atau semiologi merupakan terminologi yang merujuk pada ilmu yang sama. Istilah semiologi lebih banyak digunakan di Eropa, sedangkan simiotik lazim dipakai oleh ilmuwan Amerika. Istilah yang berasal dari bahsa Yunani semeion yang berarti 'tanda' atau 'sign', dalam bahsa inggris itu adalah ilmu yang mempelajari system tanda seperti: bahasa, kode, sinyal dan sebagainya.

Dalam pengertian yang sama, karya seni rupa dapat dianggap sebagai sebuah 'teks' karena merupakan 'kombinasi elemen tanda-tanda', dengan kode dan aturan tertentu sehingga menghasilkan sebuah ekspresi bermakna'. Dengan demikian dapat disimpulkan bahwa semiotika adalah suatu ilmu yang mempelajari keberadaan suatu tanda. Tanda merupakan sesuatu yang bersifat fisik, bisa dipersepsi oleh indra manusia, tanda mengacu pada sesuatu di luar tanda itu sendiri, dan bergantung pada pengenalan oleh penggunanya sehingga disebut tanda. Tanda-tanda tersebut kemudian dimaknai sebagai wujud dalam memahami pemaknaan dalam muatan visual.

\section{Analisis Data}

Dalam sebuah penelitian analisis sangat diperlukan karena analisis data adalah cara untuk mengolah data yang telah terkumpul agar mendapatkan hasil, temuan dan kesimpulan dari suatu penelitian yang telah dilakukan. Guna mengungkap data tersebut, peneliti melakukan langkah analisis secara deskriptif melalui beberapa tahapan, yaitu: 1) Mengidentifikasi data yang terkumpul baik teks maupun bentuk visual, yang diperoleh melalui observasi, wawancara dokumentasi dan studi literatur, 2) membaca, mempelajari dan menelaah keseluruhan data yang terkumpul, baik data yang tertulis maupun visual dan mengklasifikasikannya sesuai jenis dan sifat data, 3) Mengadakan reduksi data yang dilakukan dengan jalan yaitu membuat rangkuman inti, proses dan pernyataanpernyataan yang perlu dijaga sehingga tetap berada di dalamnya, membuat memo dan diagram sebagai proses pemusatan perhataian pada penyedarhanaan data kasar yang muncul. Dari catatan lapangan dan transkripsi wawancara tersebut dilanjutkan dengan cara pengkodean secara menyeluruh, 4)Menyusun dan mengkategorisasikan data berdasar pada masingmasing kategori permasalahan penelitian, dalam pengkodean tahap kedua, 5)mengadakan pemeriksaan data untuk menetapkan keaabsahan data sesuai dengan teori yang telah ditetapkan sebelumnya, baik secara tekstual maupun konstekstual, dan, 6) melakukan penafsiran (menginterpretasikan) data yang telah terseleksi dirangkai menjadi satu kesatuan analisis yang utuh untuk mencari makna yang lebih luas (holistik) dengan penulisan temuan berdasarkan pemikiran secara induktif.

\section{PEMBAHASAN}

\section{Psikologis Katarsis dan Seni}

Pendekatan psikoanalisis dalam sejarah seni rupa terutama berkaitan dengan aspek ketidaksadaran yang terwujud pada karya seni rupa. Metode ini kompleks karena menyangkut sisi seniman, tanggapan artistik penikmat, dan konteks kulturalnya. Metode ini sebagian pula memanfaatkan teori-teori ikonografi, feminisme, Marxisme, semiotika, dan juga psikobiografi yang mengkaji relasi perkembangan psikologis perupa dengan karyanya (Adams. 1996:179). Namun antara histori seni dan psikoanalisis memiliki perbedaan yan cukup mendasar. Antara daya kekuatan, pengaruh dari citra visual yang disajikan serta interpretasi, histori yang melatar belakangi karya memiliki peran penting pada kedua bidang tersebut. Selain itu penglaman estetis seniman ynag bersifat pribadi ikut berperan besar dalam proses terwujudnya karya.

Viusalisasi pada karya bersifat kompleks dan begitu dekat yang melibatkan kreativitas, imajinasi, mimpi bahkan candaan serta ketakutan yang dimaknai dari kehiduapan sehari-hari. Seni visual ialah sesuatu yang dilahirkan oleh individu, yang bersifat imaginatif, kreatif, berdaya peka, berpengetahuan, dan memiliki 
kepekaan terhadap keindahan untuk dinikmati secara langsung atau dapat dilihat dan dinikmati dengan mata. Seni visual dalam pembentukannya membutuhkan peranan dari jiwa yang berhubungan dengan hati yang memiliki unsur -unsur psikologi, sehingga mampu menjadikan individu yang menciptakan

keseimbangan dan berpadu secara menyeluruh dengan seni yang diciptakan.Selain itu seni visual sebagai perwujudan bentuk komunikasi seniman dengan apresiator penikmat seni, yakni melalui proses memahami dan menelaah makna dibalik seni maupun sekedar melihat dan menikmati keindahan karya seni. Proses timbal balik ini berhubungan dengan peran psikologi dalam penciptaan, penyampaian dan pemahamannya.

Dalam psikologi dengan pemaparan berbasis psikoanalisis sebagai salah satu keilmuan yang mewakili proses analitisnya/psikologi analistis. Psikoanalisis dalam kasus ini lebih kepada menggali material yang telah terjadi dari masa lalu, sehingga menjadi sejarah baru dan cerita masa kini dalam visual karya seni. Hal ini sebagaimana kasus di masa lalu Heinrich Schliemann menggali Troya dan Sir Arthur Evan menemukan peradaban Minoan, maka psikoanalisis membuka tabir masa kecil seseorang (Adams. 1996:180).

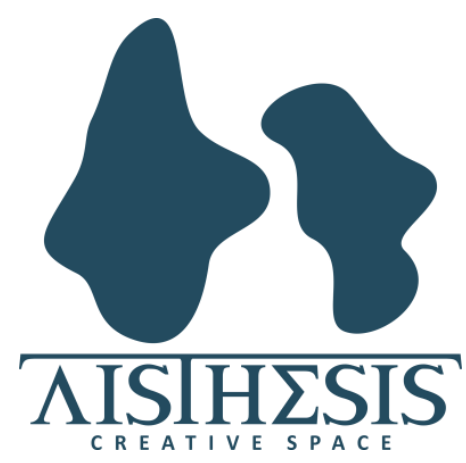

Gambar 1 .Logo Komunitas Belajar yang didirikan Seniman

\section{Psikobiografi Seniman}

\section{a. Seniman Ozaques}

Karya Kreatif melalui gagasan kritis seniman yang bertajuk Seni Fotografi sebagai Medium Representasi dari Retrospeksi Perhubungan Manusia dengan Alam Perbendaan dalam Pengalaman Traumatis dan Katarsis (Studi Fenomenologi). Pada saat itu kehadiran bentuk instalasi sabagai salah satu karya seni visual cukup berperan dalam pendalaman interpretasi atau pemnn yan tentunya tidak lepas dari keilmuan. Seniman menghadirkan representasi objek-objek berkelindan di mana audien diajak untuk bermain-main dalam dunia imajinasi tanpa batas, sebagaimana latar belakang seniman yang tidak terkungkung dan dibatasi oleh keilmuan yang linier. Selain itu seniman yang berfokus pada penciptaan seni visual kontemporer. Hal ini berawal dari seniman yang memiliki pengalaman residensial internasional pada tahun 2017 di Rumah Budaya Segaragunung dan melakukan pertukaran keterampilan artistik melalui percakapan dialektis, serta berkolaborasi dengan seniman asal Indonesia, Korea, dan Perancis. Seniman di Babaran segaragunung juga melibatkan seniman asal Jerman pada tahun 2018 dan Yunani pada tahun 2019 dalam proyek penciptaan karya visual dengan medium fotografi.

Praktik artistik seniman Ozaques memiliki kecenderungan dengan bentuk dinamis, yang menyertai setiap gagasan di balik karya-karyanya. Sebab beberapa gagasan yang belum sempat tertuang, maka dirinya memiliki banyak ide-ide kreatif. Oleh karena itu, bagi dirinya, benda-benda yang terbentuk dari intervensi artistik hingga estetik merupakan dampak dari konsep-konsep kreatif hingga pada titik ruang rasa. Hal ini kemudian berpenaruh secara teknis yang dilakukan secara spontan, serius dan fokus. Introversi dalam mengkonkritkan ide dan gagasan yang tertuang dalam beberapa citra visualnya cenderung disampaikan secara tersirat. Seniman Ozaques memiliki motivasi yang tinggi dalam berkarya. Terlebih lagi, pribadinya merupakan personal yang pendiam dan memiliki kebutuhan eksistensial yang tinggi. Untuk mencapai hal itu, seniman ozaques melakukan kajian literasi selama berpraktik artistik yang membuatnya memiliki kesadaran kuriositas terhadap pelbagai pengetahuan di luar dirinya. Selain itu pemikiran yang idealis dan berdampingan dengan kepribadian yang keras kepala muncul ke permukaan ketika sikap berhati-hati dan teliti terhadap masukan serta saran dalam setiap pengambilan keputusan. Proses kreatif penciptaan karya menjadi medium bagi kejujurannya sehingga membuatnya tampak egois dalam berkarya.

AISTHESIS Creative Space merupakan ruang berproses kreatif kesenian independen yang dibentuk pada tanggal 1 September 2019 oleh seniman asal Yogyakarta yang bernama Ozaques. Manajer AISTHESIS Creative Space ialah Uwibong. Aktivitas dan praktik artistik dilakukan di Vila Bukit Asri Fg.5 RT.12, Gunung Sempu, Kasihan, Bantul, Yogyakarta. AISTHESIS Creative Space dibangun dengan pondasi resistensi, kreatifitas, dan keberanian. Ketiga term tersebut penting untuk ditanamkan sebagai prinsip belajar dan praktik artistik agar mendapatkan pengalaman estetik, sehingga individu dapat tumbuh mengakar selaras dengan perkembangan diri selama berproses bersama ruang AISTHESIS Creative Space. Term-term itu dipahami sebagai ketahanan diri dalam menghadapi situasi yang tidak nyaman, kreatif dalam menyelesaikan pelbagai persoalan yang direpresentasikan dalam bentuk karya seni, dan berani untuk merealisasikan ide-ide dan gagasan-gagasan yang dimiliki dengan keseimbangan 'logika-nalar dan logika-rasa'. 
Prinsip belajar dan praktik artistik ini didasari dengan falsafah jawa yaitu 'ngelmu iku kelakone kanthi laku', yang dimaknai sebagai ilmu pengetahuan yang sudah didapat kemudian diterapkan dalam kehidupan sehari-hari. Di dalam ruang AISTHESIS Creative Space, ihwal itu kemudian memberikan motivasi bagi individu yang aktif berproses kreatif dan dibekali ilmu serta pengalaman oleh seniman-seniman yang terlibat di setiap program. Maka setelah individu memiliki pengetahuan eksperensial yang diperoleh dari ruang AISTHESIS Creative Space melalui belajar, berpraktik artistik, dan berproses kreatif, individu dapat menerapkan serta melibatkan pengalamannya ke dalam dunianya dan juga di kegiatan kesehariannya.

\section{b. Seniman Arif}

Seniman Arif merupakan seniman dengan cenderung tenang dan pendiam. Sifat pendiamnya berpengaruh pada aktivitas berkesenian yan dilaluinya. Gejolak perasaan, baik sedih, kecewa maupun ketakutan seakan disampaikan dan diekspresikan dalam karya seni yang diciptakannya. Salahsatunya rasa khawatir dan kesedihannya disampaikan melalui karya terbarunya dengan medium "Batik Sablon". Seniman Arif yang berlatar belakang dari penciptaan kriya tekstil, mendekatkannya pada medium-medium serat kain sebagai jalan berkesenian untuk menumbuhkan dirinya.

Karya seniman Arif dengan berangkat dari kegelisahan dan ketakutan akan punahnya kelelawar sebagai bagian dari kosmologi atau keseimbangan alam. Ketakutannya diungkapkan denan memilih media unkap kombinasi teknik batik dengan sablon. Ketakutan dan trauma lingkungan serta keseimbanan (kosmologi) menjadi bagian dalam konsep kekaryaannya. Binatang atau hewan sebagai bagian dari mikrokosmos dari alam. Dalam hal ini, seniman Arif memperlihatkan tentan kedekatan manusia dengan makhluk lainnya baik itu tumbuhan maupun binatang. Hal ini sesuai dengan pernyataan bahwa kosmologi sebagai alur proses kreatif yang melibatkan konsep berkarya, proses dan wujud karya (Ernawati,2019).

\section{Tinjauan Kekaryaan}

Seniman sebagai kreator tentu memiliki cara masing-masing dalam mengekspresikan diri dalam berkarya yang terilhami dari pengalaman artistik masing-masing. Pemilihan teknik, media, dan unsur visual yang disusun secara akurat sebagai pertimbangan keseimbangan antara logika yang berpijak pada pengetahuan, rasa yang diiringi nilai keindahan serta pengalaman estetik sebagai sumber ilham pengalaman subyektif sang seniman. Representasi karya yang dibangun dari struktur konsep/ide, makna filosofis, ekspresi bentuk melalui citra visual memprovokasi dan menggugah jiwa khalayak seni. Semua nilai yang termuat tidak lepas dari Penyatuan logika dalam kesadaran sebagai salahsatu yang berperan aktif untuk memeriksa hubungan elemen-elemen visual maupun bentuk material karya karena tidak dapat dipungkiri ide duduk dalam alam berfikir manusia yang bersifat halus dan abstrak. Selain logika, rasapun berperan dalam penyelaman jiwa mengakui akan hubungan manusia sebagai diri yang memerlukan hal diluar diri sang seniman. Guna meraih hal diluar diri tersebut perlu peleburan dan penyatuan dengan alam dan lebih jauh lagi dengan Ilahiah sebagai sumber pencipta dari semua yang ada dengan menyatukan logika dan rasa dalam satu jiwa dalam diri pelaku seni/seniman.

Kata Traumatis dan Katarsis sekilas cukup personal untuk direspon menjadi sebuah karya seni. Namun tema Perhubungan manusia dengan Alam Perbendaan cukup luas dalam upaya mengekspresikan konsep karya kreator kedalam medium seni berdasarkan kaidah konseptual dan pengalaman estetiknya. Dari aspek psikologis katarsis sebagai gambaran upaya seseorang ketika mampu melalui rasa sakit. Dibenturkan terhadap estetika kata katarsis akan menjadi indah dan bermakna ketika terwujud dalam sebuah karya. Cara pandang terhadap karya yang dihadirkan bagaiakan dua sisi mata uang logam yaitu citra visual berada dalam satu bidang yang sama namun dengan penilaian perspektif yang berbeda. Pada satu sisi seakan menggambarkan kedekatan diri manusia dengan material-material tertentu yang merupakan bagian dari alam disajikan melalui berbagai figur manusia. Sementara susunan anatomi tubuh terbentuk dari material tertentu dengan berbagai figur tubuh yang disajikan dalam bentuk karya Fotografi. Lebih jauh lagi, karya seni yang disajikan mengkomunikasikan pesan moral tentang perlunya kesadaran bahwa manusia sesungguhnya tidak berdiri sendiri namun mampu bergerak dan bertindak karena adanya yang memberikan penghidupan, yaitu alam. Realitas yang ada tidak dapat dipungkiri manusia ketergantungan dengan benda-benda lain sebagai penunjang untuk beraktivitas.

Sikap sombong dan angkuh merupakan kutukan yang tidak layak dilakukan, karena kenyataannya manusia sebagai makhluk sosial hanya insan yang tergantung dengan benda-benda lainnya baik makhluk hidup lain yang bernyawa maupun alam benda. Selain itu pesan moral tentang perlunya pengendalian diri juga ikut berperan didalamnya. Semenatara dari sisi lain, ketika kembali pada judul karya citra visual yang disajikan sebagai nilai personal merupakan representasi dari teriakan artistik mengenai rasa takut, gelisah dan luapan rasa tertekan dalam diri yang menyiksa jiwa seseorang. Wilayah personal manusia itu sendiri sebagai alam pikiran, perasaan, serta sifat, yang mempengaruhi sikap prilaku/suatu tindakan. Aspek psikologi tentu ikut berdialog dalam pemaknaan konotasi, yang tertuang dalam citra visual karya yang dihadirkan oleh seniman. Pendalaman akan pemahaman hal pada karya dalam berbagai persepektif baik aspek estetika seni maupun psikologi diluar permasalahan 'benar-tidak benar' namun sebatas 
jendela pembuka cakrawala pikiran, pengetahuan serta pendalaman rasa yang lebih luas dan utuh terhadap fenomena kedekatan dengan realitas kebendaan.

Berdasarkan kedua perspektif tersebut dapat ditarik benang merah seniman mengkomunikasikan tentang Kompleksitas perhubungan manusia dengan alam perbendaan dalam konteks pengalaman traumatis dan katarsis yang direpresentasikan dengan memilih medium fotografi, pengetahuan seni dan pengalaman baik personal maupun sosial. Hal ini cukup baik dan menarik guna mempermudah pemahaman dan lebih sederhana dalam pemaparan.

Ulasan singkat di atas sebatas pengantar pemahaman sebagai apresiator dalam menikmati karya seni phootography dalam pameran bertema "Perhubungan Manusia dengan Alam Perbendaan". Setidaknya uraian singkat tersebut, diharapkan dapat menyumbang sebagai pengantar dalam cara pandang atau perspektif bagi para penikmat seni dalam memaknai karya yang disajikan pada pameran yang membagikan pengalaman artistik melalui media digital (fotografi), dengan berangkat dari realitas kehidupan yang kompleks dan begitu dekat dalam kehidupan manusia. Dari beberapa karya seniman dalam pameran, diantaranya sebagai berikut:

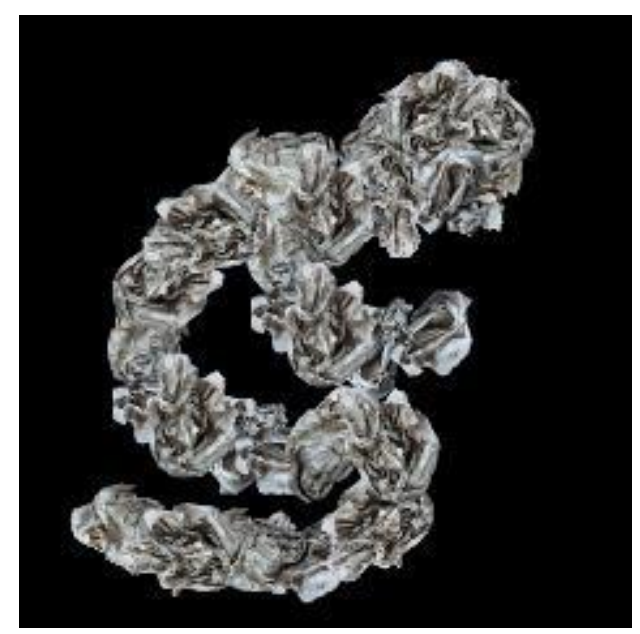

Gambar 2

Perupa : Ozaques

Ukuran : $50 \mathrm{~cm}$ x $75 \mathrm{~cm}$

Judul : Keberadaan Subjek dan Benda Autentiknya Tahun : 2019

Fotografi dengan judul'Keberadaan Subjek dan Benda Autentiknya " pada media Digital Print on Ivory Paper-Doff Lamination berukuran $50 \mathrm{~cm} \mathrm{x}$ $75 \mathrm{~cm}$, tampak bersifat umum lebih kepada kesadaran kehidupan manusia yang dinamis, mengarahkan dan membawa manusia pada pola kehidupan yang cukup kompleks dan mendesak sehingga sampai pada titik manusia memiliki keterbatasan. Keterbatasan sebagai bagian dari permasalahn hidup memicu rasa frustasi dan cenderung menunjukan sisi gelap sesorang. Representasi figur manusia yang dihadirkan tentang bagaimana mereka memposisikan diri dalam mengatasi kepelikan, keterbatasan kemampuan maupun hambatan dalam pengalaman traumatis yang menimpa diri. Posisi subyek manusia dengan menghadap kebelakang dan Warna hitam mengkomunikasikan sisi gelap dari kegelisahan dan rasa tertekan. Figur yang mulai menghadap kesamping dan dilanjutkan dengan menghadap dan berani menatap kedepan dengan senyum simpulnya dapat dipandang sebagai cara atau jalan manusia berusaha melalui serta dapat mengatasi pengalaman trauma dan rasa sakit dalam kehidupan guna melanjutkan dan menghadapi kehidupannya.

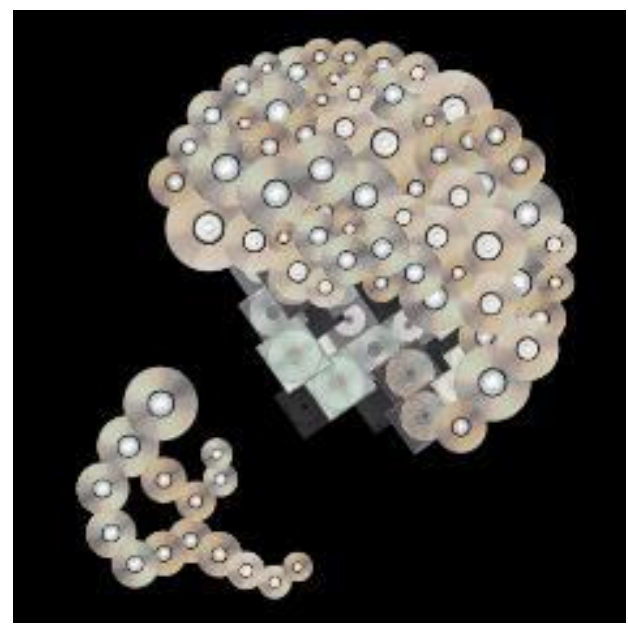

Gambar 3

Perupa : Ozaques

Ukuran : $40 \mathrm{~cm}$ x $40 \mathrm{~cm}$

Judul : Kegeisahan dan Kemurungan Tahun : 2019

Karya berjudul "Kegelisahan dan Kemurungan "yang disajikan melalui media Digital Print on Ivory Paper-Doff Lamination berukuran $40 \mathrm{~cm} \times 40 \mathrm{~cm}$, seniman sebagai kreator seakan maju melangkah lebih dekat, intim dan menyatu dari judul karya sebelumnya "Keberadaan Subyek dan Benda Autentiknya"yang masih terpisah antara subyek manusia dengan obyek benda. Pada karya kedua ini mengantarkan penyampaian kesatuan benda dan manusia dalam satu batang tubuh figur manusia yang merepresentasikan rasa takut, gelisah, sakit dan terancam dari pengalaman hidup seseorang. Bendabenda yang dipilih seniman sebagai kreator kemungkinan sebagai bagian dari alur cerita pengalaman traumatis yang termuat dalam pemaknaan kehidupan seseorang ataupun sebatas pendekatan makna dari sifat yang dimiliki tiap obyek benda. Terlepas dari berbagai benda yang dipilih, benda mati yang disusun sedemikian rupa membentuk figur manusia yang bernyawa yang tumbuh menjadi visual yang seakan hidup dan berbicara pada audien dalam berbagai ekspresi visual. Lebih jauh lagi karya ini, menekankan kesadaran akan kesatuan utuh visual dengan perasaan yang diluapkan berdasarkan pengalaman seseorang. 3)Lanjut dengan karya dengan judul" Luapan Emosi Jiwa", dengan media Digital 
Print on Flexy berukuran: $100 \mathrm{~cm}$ x $1000 \mathrm{~cm}$. Karya ini disajikan dengan citra/bentuk visual dikolase secara kolektif. Cita visual pada karya ini lebih kongkrit memperlihatkan berbagai ekspresi memperjelas dari hasil pengalaman batin personal berdasarkan figur pada karya sebelumnya. Karya ini seakan menjadi puncak dari alur karya kesatu dan kedua. Seumpama kata badai pasti berlalu, berbagai ekspresi pada karya "Luapan Emosi Jiwa" Seniman seakan menyampaikan proses melalui rasa takut dan kegelisahan, berakhirya trauma dan rasa takut dengan berfikir dan bertindak secara reflektif untuk keseimbangan dalam diri. Setiap insan manusia memiliki cara mengekspresikan diri dalam mengatasi masalah kehidupan yang menyakitkan serta menyedihkan. Berkarya dengan tema traumatis dan katarsis bagi seniman berdasarkan karya yang disajikan merupakan proses transformasi melepas ketegangan emosi dan energi psikis yang tertekan melalui karya seni. Fotografi salah satu media untuk mensublimasikan naluri ketakutan, rasa sakit, dan gerakan ke dalam bentuk karya yang dapat diapresiasi dengan baik oleh masyarakat.

Melalui karyanya Ojaq menyampaikan sisi gelap seseorang, perasaan kelam, amarah, kesedihan, teror, dan ketakutan yang direpresentasikan secara visual dengan pendekatan wujud material alam benda sebagai penetralisir kedekatan dalam kehidupan seharihari. Karya Fotografi dari Ojaq adalah bukti bagaimana seorang seniman fotografer sebagai author mempunyai keterampilan untuk berbagi mata dalam berbagi cara pandang suatu fenomena, dan berbagi ungkapan dalam kata dengan mengkomunikasikan pesan dalam karya.

Memilih alur berkesenian berdasarkan kedekatan dengan benda atau material dalam kehidupan sehari-hari melalui medium fotografi oleh seniman membuat benda mati menjadi makhluk hidup dan manusia sebagai makhluk hidup menjadi makhluk cerdas yang sadar diri. Lebih jauh lagi, mencerminkan sebuah kesadaran akan adanya hubungan timbal-balik, kesatuan, kedekatan dan diaolg saling menerima antara manusia dengan alam benda sekitar. Konsep berdasarkan realitas kehidupan kedekatan hubungan manusia dengan alam benda merupakan tradisi keseharian yang membentuk budaya. Karya fotografi bukan sebatas penjara kekakuan imitasi obyek gambar semata, tetapi sebaliknya karya seni sebagai tradisi juga keseharian dan kebiasaan yang dilaksanakan secara terus menerus dalam kehidupan keseharian. Benda adalah wujud yang berperan dan bernilai ketika dimaknai dan digunakan dalam berkarya. Berkesenian dengan jalan kesadaran akan benda sekitar membuka tantangan untuk melakukan petualangan dan penjelajahan artistik serta estetik dalam urgensi dalamnya nilai memaknai benda sebagai bagian dari peristiwa budaya berkesenian. Dengan demikian manusia akan menemukan peran yang tepat untuk dirinya di alam semesta, sehingga memaknai interaksi antara manusia dengan alam benda akan dapat dipertanggungjawabkan secara etis. Begitulah secara fakta bahwa kita adalah sebentuk kesatuan dengan kedekatan yang terbangun dengan alam benda yang berperan dalam gerak dan aktifitas dalam kompleksitas kehidupan keseharian.

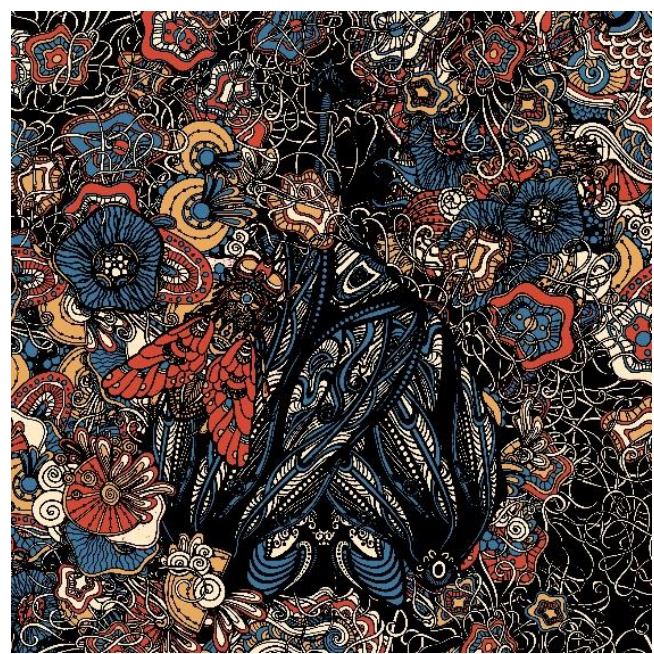

Gambar 4

Seniman: Arif

Berhenti Makan

Batik sablon malam pada kain primisima, $100 \mathrm{~cm} \times 100 \mathrm{~cm}, 2019$

Pada karya ini visual kelelawar yang menutupi dari mata sampai ke bawah, seekor lalat, granat, dan disekililing kelelawar terdapat tanaman yang terinfeksi pestisida. Kreasi bentuk dan warna ikut berperan pada karya. Warna backroun/latar hitam menimbulkan sisi kegelapan dan di sisi lain menciptakan kreasi warna (biru, jina,kuning, putih) pada obyek visual lebih muncul kepermukaan. Metafor granat yang diartikan bila sewaktu-waktu hewan ini dapat terancam punah bahkan dapat punah. Karya ini menggambarkan kelelawar pemakan serangga tidak mau memakan serangga yang terjangkit bahan kimia pestisida, walaupun serangga lalat hinggap ditubuhnya. Inspirasi karya ini adalah rasa takut dan wujud keprihatinan akan lemahnya pengetahuan manusia terhadap dampak pestisida untuk kelelawar. Dari salah satu bahan ini dapat membunuh populasi jenis hewan mamalia.

Penggunaan pestisida terhadap seranggaserangga yang dianggap hama, ternyata juga dapat mengganggu populasi kelelawar. Hal tersebut terjadi saat serangga yang telah memakan tumbuhan yang mengandung pestisida itu dikonsumsi oleh kelelawar betina, dan pestisida itu akan mempengaruhi air susu kelelawar tersebut. Kelelawar merupakan hewan mamalia (menyusui), akibatnya berdampak masuknya racun ke bayi kelelawar yang mempengaruhi kelangsungan hidupnya. Apalagi pada saat bayi, sistem kekebalan tubuhnya sangatlah rentan terkena penyakit mematikan. Padahal, kelelawar dapat sangat membantu untuk menyeimbangkan ekosistem, termasuk membantu kehidupan sehari-hari manusia. 


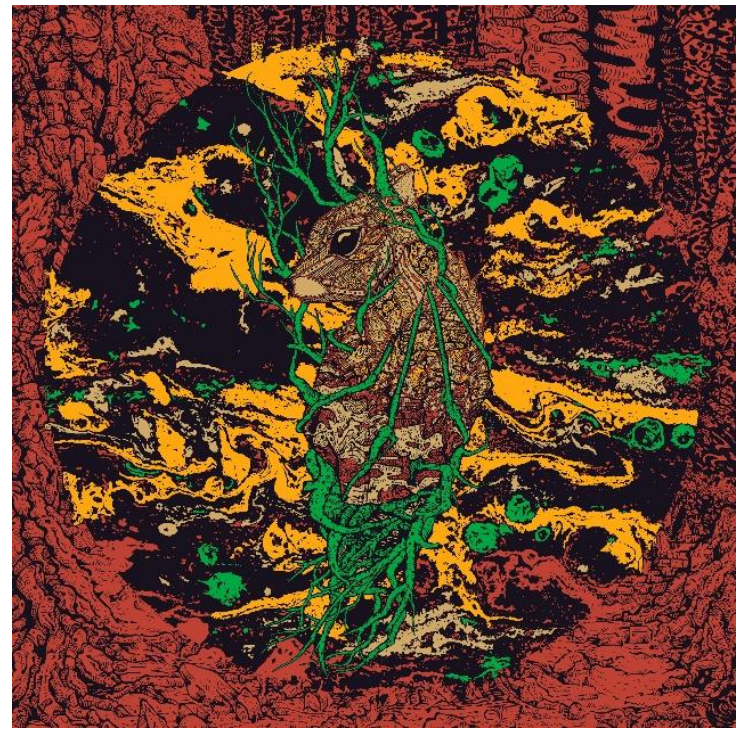

Gambar 5

Seniman: Arif

Judul : Seperti pohon, B

Teknik Media : Batik sablon malam pada kain primisima,

Ukuran :100cm x 100cm, 2019.

Pada visual karya ini menampilkan objek kelelawar dan objek pohon. Lingkaran yang dibuat seperti bola dunia dengan serat kasar sebagai unsur rupa yaitu terkstur yang ditampilkannya. Belakangnya terlihat suasana hutan. Deformasi bentuk kelelawar yang diambil beberapa bagian anggota tubuh mulai dari kepala sampai sayap dengan terjerat serat-serat berwarna hijau. Deformasi pohon juga diambil dari batang, tekstur batang pohon, dan akar. Karya ini mendiskripsikan hewan kelelawar yang akan menjadi pohon.

Kelelawar dalam fungsi ekologi sangat penting karena hewan itu menjaga keanekaragaman tumbuhan hutan tropis. Reboisasi secara alami dapat dilakukan melalui proses penyebaran biji polinasi dengan bantuan kelelawar. Kelelawar umumnya tinggal di hutan yaitu menggantung pada pohon-pohon besar, pohon-pohon yang berlubang, pohon besar bekas tebangan, kayu mati dan pohon kelapa. Karya yang berjudul seperti pohon ini, terdapat nilai simbolik tentang manusia yang bertindak dalam mengeksploitasi kelelawar yang seharusnya memikirkan dampak yang lain. Manusia sibuk mencari sumber kekayaan alam akan tetapi lupa untuk merawat kelestarian dari hewan itu sendiri.

\section{KESIMPULAN}

Penulisan kajian karya seni rupa dari perspektif psikologis katarsis mengantarkan apresiator pada suasana mental (mood) yang melatar belakangi proses kekaryaannya. Perspektif akan lebih obyektif karena seniman sebagai kreator berbanding lurus dengan karya yang disajikan. Elemen visual yang dipilih dan disajikan seniman tidak tersusun begitu saja, namun berdasarkan kemampuan kreatif menyusun citra visual yang berangkat dari aspek pengalaman yaitu berupa rasa khawatir/kegelisahan serta ketakutan yang mendasarinya dalam berkarya. Karya seni merupakan representasi dari dunia psikis seniman sebagai kreator. Pendekatan psikologis dalam berkarya dengan dipadukan kemampuan akademik dari aspek keilmuan seni rupa setidaknya mampu memperkaya keilmuan dalam keberagaman seni rupa.

\section{DAFTAR PUSTAKA}

Adams, L.S. 1996. The Methodologies of Art: An Introduction. Boulder, Colorado: Westview Press

Alex Sobur, 2006. Analisis Teks Media. Bandung: Remaja Rosdakarya

Benson, Nigel C dan Simon Grove. (Terjemahan Medina Chodijah). 2000.Mengenal Psikologi for Beginners. Bandung: Mizan.

Barrett, T. 1994. Criticizing Art, Understanding the Contemporary. California: Mayfield Publishing Company.

Ernawati, "Kosmologi sebagai Pijakan Kreasi dalam Berkarya Seni," INVENSI, vol. 4, pp. 113-129, 2019.

Freud, S. 1947. Leonardo da Vinci: A Study in Psychosexuality. New York: Random House.

Freud, Sigmund. (Terjemahan Yuli Winarno). 2002. Kenangan Masa Kecil Leonardo da Vinci. Jogjakarta: Jendela

Panuti Sudjiman dan Aart Van Zoest, 1992. Serba-serbi Semiotika. Jakarta: Gramedia Pustaka Utama,

Sriwahyuninsih, "Katarsis dan perubahan Sosial”, 2017. Komunikasi, Vol. XI No. 01, Maret 2017: 395240.Trunojoyo, Madura. 